\title{
PENAMBAHAN TAURIN MELALUI ROTIFER Brachionus rotundiformis UNTUK PERBAIKAN PERTUMBUHAN LARVA DAN PENINGKATAN PRODUKSI BENIH KERAPU SUNU, Plectropomus leopardus
}

\author{
Regina Melianawati dan Ni Wayan Widya Astuti \\ Balai Besar Penelitian dan Pengembangan Budidaya Laut \\ Jl. Br. Gondol, Kec. Gerokgak, Kab. Buleleng, Kotak Pos 140, Singaraja, Bali 81101 \\ E-mail: regina_melianawati@yahoo.com
}

(Naskah diterima: 1 Maret 2012; Disetujui publikasi: 16 Oktober 2012)

\begin{abstract}
ABSTRAK
Ikan kerapu sunu Plectropomus leopardus merupakan komoditas perikanan laut yang bernilai ekonomis tinggi, sehingga perlu dikembangkan dalam skala budidaya. Untuk meningkatkan keberhasilan pembenihan maka kualitas rotifer Brachionus rotundiformis sebagai pakan alami bagi larva perlu ditingkatkan. Uji coba penggunaan taurin sebagai salah satu bahan pengkaya rotifer perlu dilakukan, mengingat taurin merupakan asam amino bebas yang diharapkan dapat diabsorbsi dengan mudah dan cepat oleh larva. Penelitian ini bertujuan untuk mengetahui pengaruh penambahan taurin terhadap pertumbuhan dan sintasan larva kerapu sunu. Penelitian dilakukan pada bak berkapasitas 6.000 liter. Selama pemeliharaan larva diberi fitoplankton Nannochloropsis ocullata, rotifer, dan Artemia, serta pakan buatan. Perlakuan yang diujikan adalah: (A) penambahan taurin dan (B) tanpa penambahan taurin. Penambahan taurin dilakukan melalui proses bioenkapsulasi pada rotifer. Parameter yang diamati meliputi: panjang total, pertumbuhan duri sirip punggung dan perut, jumlah rotifer yang dikonsumsi oleh larva, serta sintasan benih. Hasil penelitian menunjukkan bahwa larva kerapu sunu umur 25 hari pada perlakuan A memiliki panjang total lebih besar $(7,00 \pm 0,83 \mathrm{~mm})$ dibandingkan pada perlakuan $B(6,39 \pm 0,85 \mathrm{~mm})$. Pertumbuhan duri sirip punggung dan perut larva pada perlakuan A terjadi lebih cepat dibandingkan pada perlakuan B. Jumlah rotifer yang dikonsumsi oleh larva pada perlakuan A lebih banyak dibandingkan pada perlakuan B. Secara statistik, semua parameter yang diamati tersebut berbeda nyata pada kedua perlakuan $(P<0,05)$. Sintasan benih kerapu sunu pada perlakuan $A$ lebih tinggi $(1,45 \%)$ dibandingkan pada perlakuan $B(0,01 \%)(P<0,01)$. Dengan demikian maka penambahan taurin dapat meningkatkan pertumbuhan dan sintasan larva kerapu sunu.
\end{abstract}

KATA KUNCI: taurin, pertumbuhan, sintasan, larva, kerapu sunu

ABSTRACT: The addition of taurine through rotifers Brachionus rotundiformis to improve the growth of larvae and to increase seed production of coral trout (Plectropomus leopardus). By: Regina Melianawati and Ni Wayan Widya Astuti

Coral trout grouper is an economically marine commodity and is important to scale up its culture. To increase the successful of its culture, the quality of rotifer Brachionus rotundiformis as live feed for larvae, should be improved. Trial on the use of taurine as an enrichment ingredient in rotifers necessary to be done because as a free amino acid, taurine is expected to be absorbed by larvae easily and rapidly. This experiment was aimed to know the influence of taurine addition to growth and survival rate of coral trout larvae. The larvae were reared in 6,000 litre tanks. Phytoplankton Nannochloropsis ocullata, rotifers, Artemia, and artificial feed were given as feed 
during rearing period. The treatment was (A) taurine addition and (B) without taurine addition. The enrichment process was done through bioencapsulated by rotifers. Investigated parameters were total length of larvae, growth of dorsal and ventral spine, number of rotifers consumed by larvae and survival rate of larvae. The results indicated that total length of 25 days old coral trout larvae on treatment $A$ was bigger $(7.00 \pm 0.83 \mathrm{~mm})$ than those of treatment $B(6.39 \pm 0.85 \mathrm{~mm})$. The growth of dorsal spine and ventral spine on treatment $A$ were faster than those on treatment $B$. Number of rotifers consumed by larvae on treatment $A$ was more than those on treatment $B$. Statistically, all of those parameters was significantly different $(P<0.05)$. While survival rate of coral trout larvae on treatment $A$ was higher (1.45\%) than those of on treatment $B(0.01 \%)(P<0.01)$. In summary, the addition of taurine during larval period could increase the growth and survival rate of coral trout larvae.

\section{KEYWORDS: taurine, growth, survival rate, coral trout, larvae}

\section{PENDAHULUAN}

Ikan kerapu sunu (Plectropomus leopardus) merupakan salah satu komoditas perikanan laut yang bernilai ekonomis penting. Untuk dapat memenuhi kebutuhan pasar dan sekaligus menjaga kelestariannya di alam, maka ikan kerapu sunu perlu dibudidayakan. Hingga saat ini produksi benih ikan kerapu sunu di Balai Besar Penelitian dan Pengembangan Budidaya Laut (BBPPBL) sudah dapat dilakukan, namun sintasannya masih rendah dan belum ada kesinambungan produksi. Umumnya mortalitas tertinggi terjadi pada stadia larva.

Salah satu faktor yang diduga menjadi penyebab terjadinya kematian yang tinggi pada stadia larva adalah faktor pakan. Pakan merupakan sumber energi dalam proses pertumbuhan (Anonim, 1993). Pakan yang diberikan pada stadia larva adalah pakan alami dan jenis pakan alami yang umum digunakan bagi larva ikan laut adalah rotifer Brachionus rotundiformis. Untuk meningkatkan kualitas dan nilai gizinya, maka rotifer diperkaya dengan bahan pengkaya terlebih dulu sebelum diberikan sebagai pakan larva (Lubzens \& Zmora, 2003). Beberapa bahan yang dapat digunakan sebagai bahan pengkaya bagi rotifer adalah asam lemak dan antibiotik (Lubzens et al., 1989), vitamin (Jusadi et al., 1995), protein (Bengtson, 2003), dan taurin (Lunger et al., 2007). Rotifer yang berasal dari hasil kultur hanya mengandung taurin sebanyak $2,42 \%$ dari total asam amino bebas yang dikandungnya (Aragao et al., 2004 dalam Putra, 2008).

Taurin merupakan asam amino bebas yang disintesis dari asam amino metionin dan sistein. Taurin memiliki banyak fungsi, di antaranya membantu pembentukan asam empedu yang berfungsi dalam penyerapan lemak sehingga dapat terbentuk sumber energi yang cukup untuk menunjang pertumbuhan (Anonim, 2011 a), juga berperan dalam fungsi retina (Altshuler et al., 1993). Taurin berasal dari bahasa Latin taurus, yang artinya banteng Bos taurus, karena taurin diperoleh pertama kali dari empedu banteng oleh ilmuwan Austria Friedrich Tiedemann dan Leopold Gmelin pada 1827 (Anonim, 2011b). Taurin hanya terdapat dalam sumber protein hewani dan tidak terdapat pada sumber protein nabati. Komoditas perikanan laut umumnya kaya dengan taurin (Apriadji, 2010).

Aplikasi taurin sebagai bahan tambahan dalam pakan sudah pernah diujicobakan pada beberapa spesies ikan dan hasilnya menunjukkan bahwa penambahan taurin dapat meningkatkan pertumbuhan dan perkembangan larva ikan Japanese flounder Paralichthys olivaceus (Chen et al., 2005), yuwana ikan Japanese flounder (Park et al., 2001), dan yuwana cobia Rachycentron canadum (Lunger et al., 2007). Bagi ikan Japanese flounder, taurin juga berpengaruh terhadap perilakunya yang normal, sehingga taurin mungkin merupakan elemen yang esensial pada stadia awal kehidupannya (Takeuchi, 2001).

Atas dasar pertimbangan tersebut maka penambahan taurin melalui rotifer untuk ikan kerapu sunu diharapkan juga dapat meningkatkan dan mempercepat pertumbuhan larva sehingga periode pemeliharaan dapat lebih dipersingkat dan produksinya dapat meningkat. Penelitian ini bertujuan untuk mengetahui pengaruh penambahan taurin terhadap pertumbuhan larva dan sintasan benih ikan kerapu sunu. 


\section{BAHAN DAN METODE}

Penelitian dilakukan di Balai Besar Penelitian dan Pengembangan Budidaya Laut (BBPPBL) Gondol, Bali. Pemeliharaan larva sebagai hewan uji dilakukan dalam 2 buah bak beton yang berkapasitas maksimum 6.000 liter dan dilengkapi dengan sistem aerasi. Bak pemeliharaan tersebut ditempatkan di dalam hatcheri semi outdoor.

Pembenihan ikan kerapu sunu dilakukan dengan mengikuti pedoman cara pembenihan ikan yang telah ada (Sugama et al., 2001; Suwirya et al., 2006). Telur yang digunakan adalah telur yang fertil, berwarna jernih, dan pada saat diseleksi berada dalam keadaan terapung, kemudian ditebar dengan kepadatan 10-15 butir/L.

Selama pemeliharaan larva, ke dalam tangki pemeliharaan diberikan fitoplankton Nannochloropsis ocullata yang berasal dari kultur massal pada pagi hari mulai larva umur 2 hari. Pemberian plankton dilakukan dengan terlebih dulu menampung fitoplankton yang berasal dari kultur massal ke dalam tangki fiber berkapasitas 100-200 liter, kemudian mengalirkannya secara perlahan dengan menggunakan selang aerasi ke dalam tangki pemeliharaan larva. Pakan alami berupa zooplankton rotifer Brachionus rotundiformis mulai diberikan pada hari kedua sore dengan kepadatan awal 5-10 ind./mL. Pakan buatan berupa mikro pelet mulai diberikan setelah larva berumur lebih dari 10 hari. Waktu pemberian dan jumlah pakan buatan yang diberikan disesuaikan dengan kondisi pertumbuhan larva. Artemia mulai diberikan pada larva umur 20 hari ke atas.

Perlakuan pada penelitian ini adalah penambahan taurin sebagai bahan pengkaya pada rotifer sebelum rotifer tersebut digunakan sebagai pakan alami bagi larva. Perlakuan yang diujikan adalah (A) dengan penambahan taurin dan (B) tanpa penambahan taurin sebagai kontrol. Pada perlakuan (A) penambahan taurin dilakukan melalui proses bioenkapsulasi pada rotifer. Taurin ditimbang sebanyak 100 mg (Chen et al., 2005) kemudian ditambahkan ke dalam $40 \mathrm{~L}$ media pengkayaan rotifer. Setelah 2-3 jam, rotifer yang telah diperkaya dengan taurin tersebut kemudian dipanen, dicuci, dan diberikan sebagai pakan ke dalam media pemeliharaan larva. Pemberian taurin ini dilakukan setiap hari selama larva masih diberi pakan rotifer.
Parameter yang diamati meliputi pertumbuhan panjang total larva, panjang duri sirip punggung dan perut larva, serta jumlah rotifer dalam pencernaan larva dan sintasan benih pada akhir penelitian. Pengukuran dilakukan terhadap lima ekor sampel larva dari setiap perlakuan. Pengukuran panjang dilakukan dengan menggunakan stereoskopis mikroskop yang dilengkapi dengan mikrometer. Jumlah rotifer dalam pencernaan larva diketahui dengan cara membedah alat pencernaan larva kemudian menghitung jumlah rotifer yang terdapat di dalamnya. Penghitungan tersebut dilakukan dengan mikroskop binokuler. Data dari masing-masing parameter tersebut kemudian dianalisis secara statistik dengan uji t untuk mengetahui ada tidaknya perbedaan di antara kedua perlakuan yang diujikan (Rosner, 1995).

\section{HASIL DAN BAHASAN}

Pemberian taurin dalam pakan alami zooplankton rotifer nampak berpengaruh terhadap ukuran panjang total larva kerapu sunu (Gambar 1). Larva yang diberi taurin dalam pakan alaminya cenderung berukuran lebih besar dibandingkan dengan kontrol. Larva umur 25 dan 30 hari yang diberi taurin masingmasing berukuran panjang total 10,80 1,32 $\mathrm{mm}$ dan 15,84 $\pm 2,16 \mathrm{~mm}$; sedangkan pada kontrol panjang totalnya masing-masing $9,56 \pm 1,32 \mathrm{~mm}$ dan $12,73 \pm 1,22 \mathrm{~mm}$. Hasil ini mengindikasikan bahwa pertumbuhan larva yang diberi penambahan taurin adalah lebih baik dibandingkan pada larva kontrol.

Hasil analisis statistik menunjukkan bahwa panjang total larva dari dua perlakuan yang diujikan, mulai larva umur 1 hingga 5 hari adalah tidak berbeda nyata $(P>0,05)$. Hal ini disebabkan karena larva dari dua perlakuan tersebut masih mendapat perlakuan yang sama. Namun mulai umur 10 hingga 30 hari panjang total larva dari dua perlakuan tersebut menunjukkan adanya beda nyata $(P<0,05)$. Hal ini menunjukkan bahwa penambahan taurin berpengaruh terhadap panjang total larva.

Larva kerapu sunu, yang secara taksonomis digolongkan sebagai famili Serranidae, memiliki ciri yang spesifik berupa adanya duri sirip punggung dan perut yang nampak tumbuh memanjang dan kemudian akan memendek (Fukuhara \& Fushimi, 1988). Oleh karenanya, ukuran duri sirip tersebut dapat dijadikan sebagai salah satu indikator pertumbuhan bagi larva ikan kerapu sunu. 


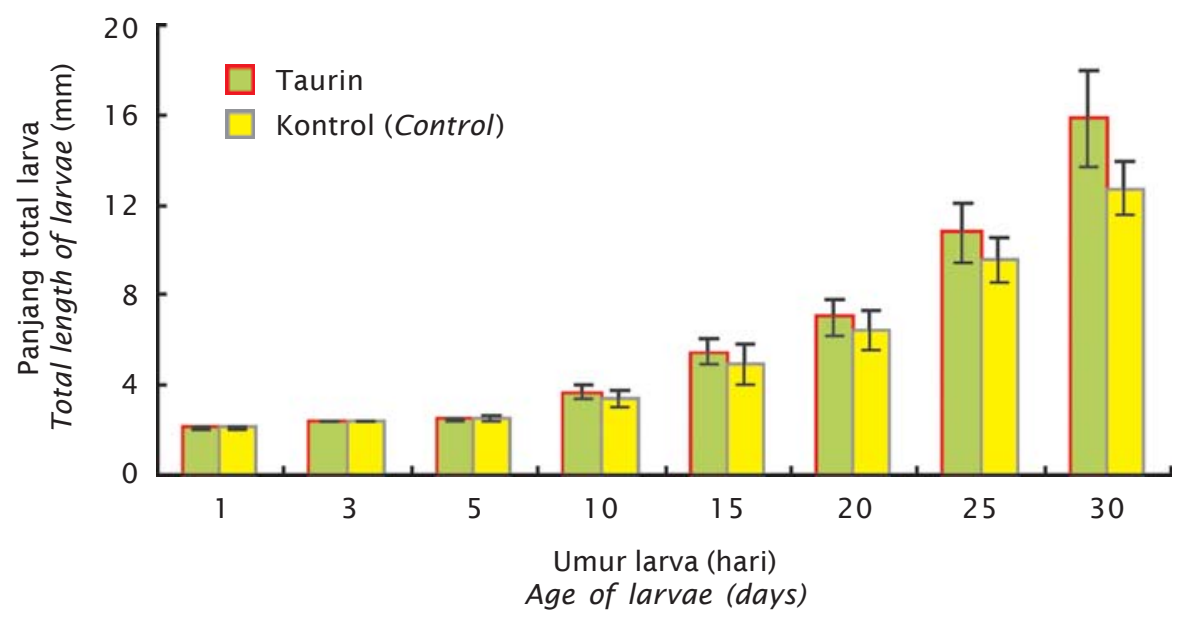

Gambar 1. Panjang total larva kerapu sunu dari masing-masing perlakuan

Figure 1. Total length of coral trout larvae from each treatment

Duri sirip punggung dan sirip perut larva mulai terdeteksi pertumbuhannya sejak larva kerapu sunu berumur 7-8 hari, namun baru terukur mulai larva umur 10 hari (Gambar 2 dan 3). Pada larva umur 25 hari, panjang duri sirip punggung dan perut larva yang diberi taurin masing-masing adalah $6,71 \pm 0,35 \mathrm{~mm}$ dan 5,00 $\pm 0,70 \mathrm{~mm}$; ukuran tersebut lebih besar dibandingkan pada larva kontrol yang

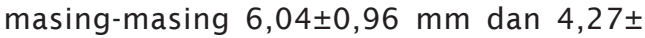
$0,58 \mathrm{~mm}$. Pada larva umur 30 hari terjadi hal yang sebaliknya, di mana panjang duri sirip punggung dan perut larva yang diberi taurin masing-masing adalah $6,99 \pm 1,37 \mathrm{~mm}$ dan 4,88 $\pm 0,64 \mathrm{~mm}$; sedangkan pada larva kontrol ukuran duri siripnya lebih besar, masingmasing adalah 7,13 $\pm 0,76 \mathrm{~mm}$ dan $4,96 \pm 0,47$ $\mathrm{mm}$. Hal ini diduga karena proses pertumbuhan duri sirip pada larva yang diberi taurin sudah mengalami fase reduksi sehingga ukurannya memendek, sedangkan pada larva kontrol justru masih dalam fase pertumbuhan sehingga ukurannya masih mengalami peningkatan. Hal ini dapat pula mengindikasikan bahwa pertumbuhan pada larva kontrol lebih lambat dibandingkan pada larva yang diberi taurin.

Hasil analisis statistik menunjukkan bahwa panjang duri sirip punggung dan duri sirip perut larva dari kedua perlakuan menunjukkan adanya beda nyata $(P<0,05)$ pada larva umur 10 dan 25 hari, sedangkan pada larva umur 15,20 , dan 30 hari tidak berbeda nyata $(P>0,05)$.
Umumnya aplikasi penggunaan taurin dilakukan pada ikan yang sudah mencapai stadia yuwana. Penambahan taurin dilakukan dengan cara mencampurnya dalam pakan buatan yang diberikan bagi yuwana tersebut. Pada beberapa spesies ikan, penambahan taurin dalam pakannya memberi dampak pertumbuhan yang lebih baik. Yuwana ikan guppy (Poecilia reticulata) dan benih ikan eel (Anguilla anguilla) yang pakannya diberi taurin masing-masing sebanyak $500 \mathrm{mg} / 100 \mathrm{~g}$ pakan dan $1.000 \mathrm{mg} / 100 \mathrm{~g}$ pakan, ternyata seluruh badan dan jaringan badannya mengandung kadar taurin lebih tinggi dibandingkan pada yuwana dan benih yang tidak diberi penambahan taurin dalam pakannya (Sakaguchi et al., 1988) yuwana ikan seabass Dicentrarchus labrax bahkan cenderung memilih pakan yang diberi penambahan taurin sebanyak $0,2 \%$ dan $0,3 \%$ daripada yang hanya diberi taurin $0,1 \%$ ataupun tanpa taurin. Lebih lanjut hasil penelitian tersebut juga menunjukkan bahwa taurin berpengaruh terhadap pertumbuhan seabass dan yuwana ikan seabass tersebut memerlukan 0,2\% taurin dalam pakannya untuk mendapatkan pertumbuhan yang lebih baik (Martinez et al., 2004). Bobot badan dan persentase pertumbuhan bobot badan pada yuwana ikan Japanese flounder Paralichthys olivaceus yang diberi taurin ternyata lebih besar dibandingkan dengan yang tidak diberi taurin. Kadar taurin di seluruh badan dan dalam jaringannya juga semakin meningkat dengan peningkatan kadar taurin yang diberikan (Kim 


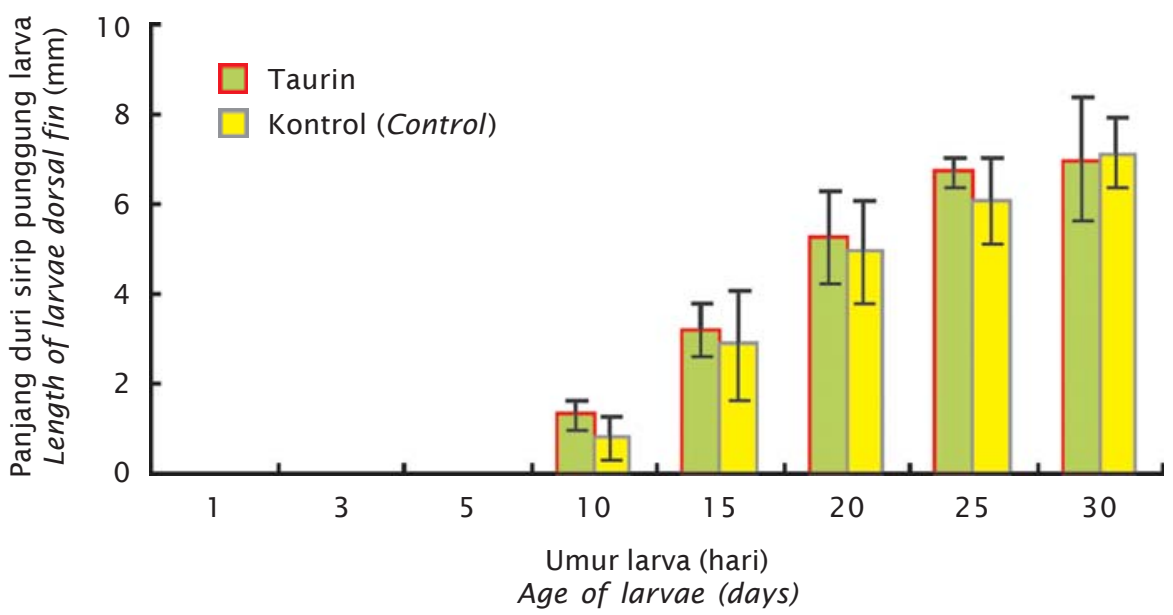

Gambar 2. Panjang duri sirip punggung larva kerapu sunu dari masing-masing perlakuan

Figure 2. Length of dorsal spine of coral trout larvae from each treatment

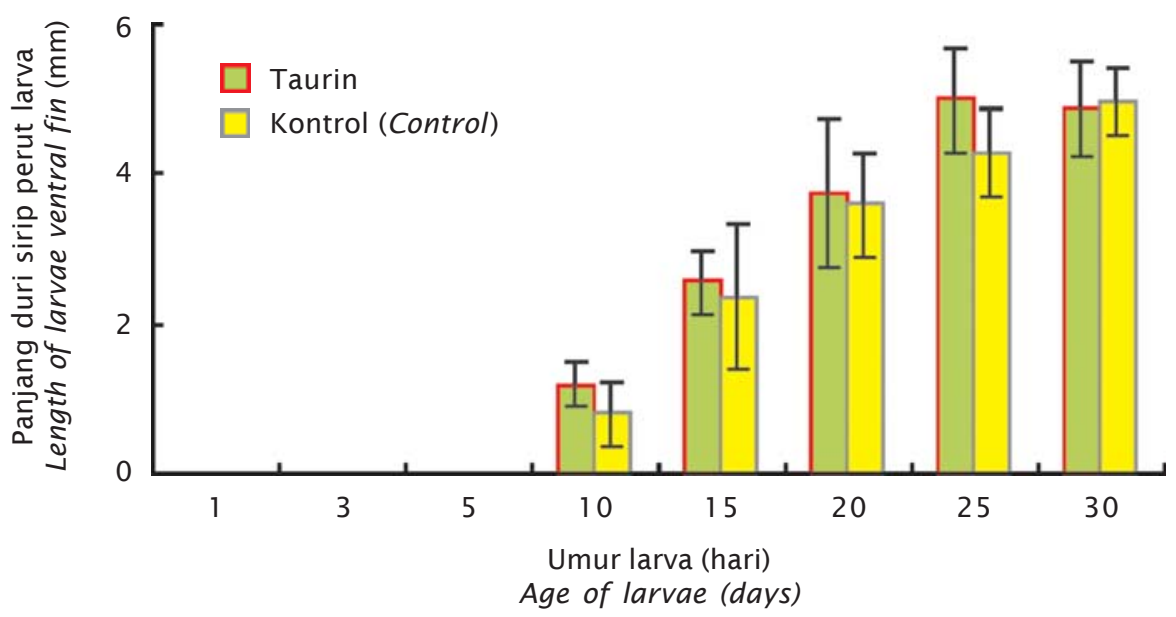

Gambar 3. Panjang duri sirip perut larva kerapu sunu dari masing-masing perlakuan

Figure 3. Length of ventral spine of coral trout larvae from each treatment

et al., 2007). Yuwana Japanenese flounder memerlukan 15-20 mg taurin/g pakan (Park et al., 2001; Takeuchi, 2001). Bagi yuwana kerapu tikus Cromileptes altivelis, penambahan taurin ke dalam pakan buatan juga berpengaruh terhadap pertumbuhannya. Penambahan taurin $0,75 \mathrm{~g}$ memberikan hasil pertumbuhan yang paling baik bagi yuwana kerapu tikus (Amalia, 2008).

Pemberian taurin bagi ikan yang masih dalam stadia larva umumnya dilakukan melalui pengkayaan dalam proses bioenkapsulasi melalui pakan alami yang digunakan sebagai pakan bagi larva. Pakan alami yang umum digunakan sebagai pakan larva ikan laut adalah rotifer. Penambahan taurin melalui rotifer ternyata berpengaruh terhadap peningkatan pertumbuhan dan perkembangan larva ikan Japanese flounder. Pengkayaan dengan taurin $400 \mathrm{mg} / \mathrm{L}$ media pengkaya merupakan kadar yang efektif (Chen et al., 2005). Penggunaan taurin sebanyak $0,5 \mathrm{~g} / 10 \mathrm{~L}$ media pengkaya ternyata juga berpengaruh terhadap peningkatan pertumbuhan dan mempercepat 
perkembangan stadia pada larva kerapu bebek (Putra, 2008).

Penggunaan taurin sebagai bahan pengkaya dalam pakan, ternyata tidak hanya diaplikasikan bagi ikan, namun juga pada udang. Penambahan taurin sebanyak $0,5 \mathrm{~g} /$ $10 \mathrm{~L}$ media pengkaya rotifer ternyata dapat mempercepat perkembangan stadia pada larva udang vaname Litopenaeus vannamei (Ruchyani, 2006; Aristyani, 2006).

Jumlah rotifer yang terdapat dalam pencernaan larva yang diberi penambahan taurin adalah lebih banyak dibandingkan pada larva kontrol (Gambar 4). Jumlah rotifer yang diberi penambahan taurin, yang dikonsumsi oleh larva umur 5, 10, dan 15 hari, masingmasing adalah 9,00 $\pm 5,34 ; 32 \pm 12,94$; dan $23,8 \pm 15,58$ individu. Sedangkan jumlah rotifer, tanpa penambahan taurin, yang dikonsumsi oleh larva umur 5,10 , dan 15 hari, masingmasing adalah $5,75 \pm 1,26 ; 10,91 \pm 6,57$; dan $16,06 \pm 11,87$ individu. Hal ini mengindikasikan bahwa penambahan taurin diduga dapat menstimulir peningkatan konsumsi pakan bagi larva, yaitu sebanyak 4-12 individu rotifer pada larva umur 5-15 hari. Hasil analisis statistik menunjukkan bahwa jumlah rotifer yang dikonsumsi oleh larva pada umur 5, 10, dan 15 hari berbeda nyata $(P<0,05)$ di antara kedua perlakuan tersebut. Larva ikan kerapu bebek yang rotifernya diberi penambahan taurin ternyata mengonsumsi rotifer dalam jumlah yang lebih banyak dibandingkan larva yang rotifernya tidak diberi penambahan taurin (Putra, 2008).

Pada akhir penelitian dapat diketahui bahwa larva yang diberi taurin menghasilkan sintasan yang lebih tinggi 1,45\%; sedangkan sintasan pada larva kontrol adalah 0,01\% (Gambar 5). Hasil ini menunjukkan bahwa pemberian taurin dalam pakan alami dapat meningkatkan sintasan larva kerapu sunu. Sebagai salah satu bentuk asam amino bebas, taurin dapat diserap secara langsung oleh sel-sel badan dan digunakan untuk proses pertumbuhan larva. Dengan adanya pertumbuhan yang baik tersebut maka tingkat sintasan larva juga meningkat yang terlihat pada sintasan diakhir penelitian. Hasil analisis statisik menunjukkan bahwa sintasan larva dari kedua perlakuan tersebut adalah berbeda sangat nyata $(\mathrm{P}<0,01)$.

Pengaruh pemberian taurin terhadap sintasan juga telah dilaporkan oleh beberapa peneliti. Sintasan larva kerapu bebek umur 16 hari yang diberi penambahan taurin mencapai $58,4 \pm 2,34 \%$; sedangkan yang tidak diberi penambahan taurin hanya $17,6 \% \pm 2,11 \%$ (Putra, 2008). Sintasan kerapu bebek umur 35 hari yang diberi penambahan taurin juga lebih tinggi yaitu $0,052 \%$; sedangkan yang tidak diberi taurin 0,03\% (Melianawati et al., 2010). Peningkatan sintasan dengan penambahan taurin juga terjadi pada larva udang vaname

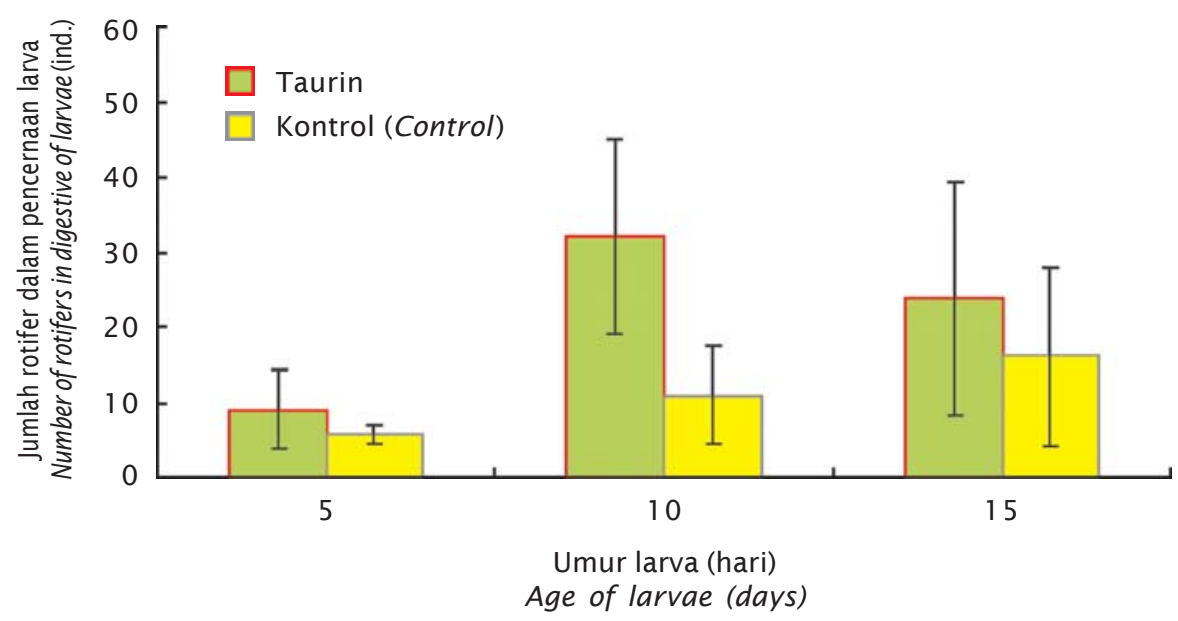

Gambar 4. Jumlah rotifer dalam pencernaan larva kerapu sunu dari masing-masing perlakuan

Figure 4. Number of rotifers in digestive system of coral trout larvae from each treatment 


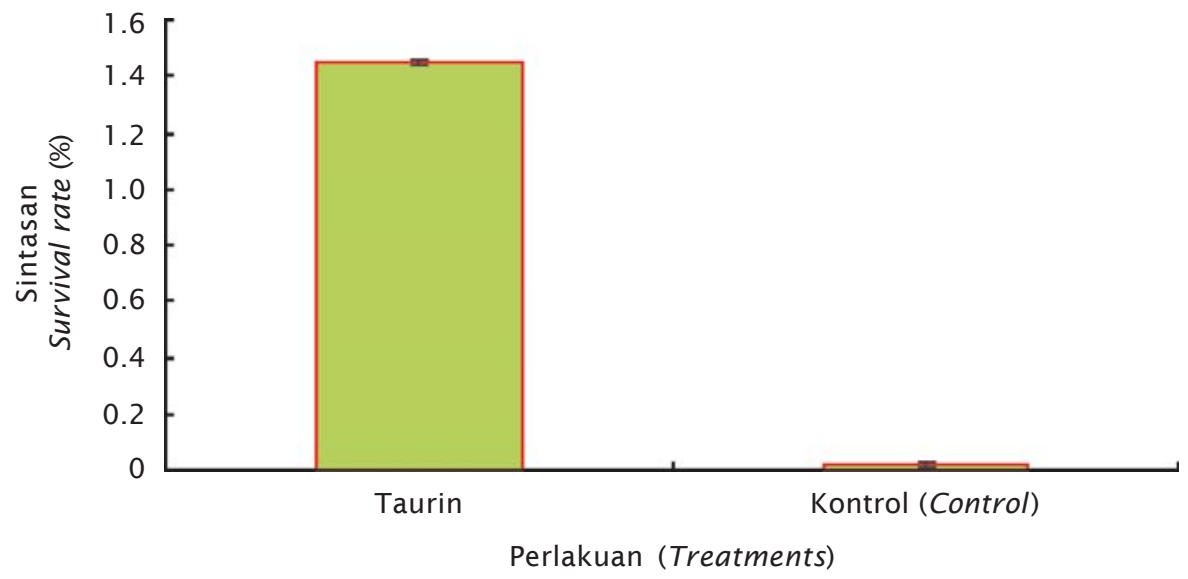

Gambar 5. Sintasan benih kerapu sunu pada umur 48 hari dari masing-masing perlakuan

Figure 5. Survival rate of 48 days old coral trout larvae from each treatment

Litopenaeus vannamei. Penambahan taurin $0,5 \mathrm{mg} / 10 \mathrm{~L}$ media pengkaya menghasilkan sintasan 53,5\% $\pm 2,8 \%$ (Ruchyani, 2006) dan $70,9 \% \pm 3,4 \%$ (Aristyani, 2006).

\section{KESIMPULAN}

- Penambahan taurin sebanyak $100 \mathrm{mg} / \mathrm{L}$ melalui bioenkapsulasi pada rotifer terbukti dapat meningkatkan pertumbuhan dan sintasan larva kerapu sunu.

- Penambahan taurin pada larva kerapu sunu berpengaruh terhadap panjang total yang lebih besar, pertumbuhan duri sirip yang lebih cepat, dan konsumsi jumlah rotifer yang lebih banyak.

\section{UCAPAN TERIMA KASIH}

Penelitian ini didanai oleh APBN melalui Proyek Riset Balai Besar Riset Perikanan Budidaya Laut Departemen Kelautan dan Perikanan Tahun Anggaran 2010. Terima kasih kepada Sdr. Mujimin dan Sdri. Made Miniarti, Teknisi Litkayasa BBPPBL, yang membantu dalam pelaksanaan penelitian ini. Terima kasih kepada Bapak Ir. Ketut Suwirya, M.S. atas sarannya terhadap penelitian ini dan kepada Bapak Drs. Bejo Slamet, M.Si., selaku Tim Pemeriksa makalah BBPPBL, yang telah membaca dan mengoreksi tulisan ini.

\section{DAFTAR ACUAN}

Altshuler, D., Lo Turco, J.J., Rush, J., \& Cepko, C. 1993. Taurine promotes the differentiation of a vertebrate retinal cell type in vitro. Development, 119: 1,317-1,328.

Amalia, B. 2008. Pengaruh penambahan taurine pada pakan buatan terhadap pertumbuhan juvenil kerapu tikus (Cromileptes altivelis). Universitas Muhammadiyah Malang. library.um.ac.id [13-01-2012].

Anonim. 1993. Dietary requirements. In: Nutrient requirements in fish. National Research Council. USA, p. 3-32.

Anonim. 2011 a. Taurin. www.news-medical. net. [07-12-2011].

Anonim. 2011 b. Taurin. wikipedia.com. [07-12$2011]$.

Apriadji, W.H. 2010. Taurin sedikit, tapi berarti. nirmalamagazines.com. [23-01-2012].

Aristyani, D. 2006. Aplikasi pemberian asam amino bebas untuk larva udang vaname Litopenaeus vannamei. Fakultas Perikanan dan IImu Kelautan, Institut Pertanian Bogor, $53 \mathrm{hlm}$.

Bengtson, D.A. 2003. Status of marine aquaculture in relation to live prey: past, present and future. In: Life feeds in marine aquaculture. J.G. StØttrup and L.A. McEvoy. (Eds.) Blackwell Science Ltd, p. 1-16.

Boyd, E.C. 1982. Water quality management for pond fish culture. Elsevier Scientific Publishing Company. Auburn University. Auburn, Alabama, $318 \mathrm{pp}$.

Chen, J., Takeuchi, T., Takahashi, T., Tomoda, T., Koiso, M., \& Kuwada, H. 2005. Effect of rotifers enriched with taurine on growth in 
larvae of Japanese flounder Paralichthys olivaceus. Nippon Suisan Gakkaishi, 71 (3): 342-347.

Fukuhara, O. \& Fushimi, T. 1988. Fin differentiation and squamation of artificial reared grouper Epinephelus akaara. Aquaculture, 69: 379-386.

Huet, M. 1971. Text book of fish culture: Breeding and cultivation of fish. Fishing News Book Ltd. England, 436 pp.

Jusadi, D., Takeuchi, T., Seikai, T., \& Watanabe, T. 1995. Hypervitaminosis and safe levels of vitamin A for larval flounder Paralichthys olivaceus fed Artemia nauplii. Aquaculture, 133(2): 135-146.

Kim, S., Matsunari, H., Takeuchi, T., Yokoyama, M., Murata, Y., \& Ishihara, K. 2007. Effect of different dietary taurine level on the conjugated bile acid composition and growth performance of juvenile and fingerling Japanese flounder Paralichthys olivaceus. Aquaculture, 273: 595-601.

Lubzen, E., Tandler, A., \& Minkoff, G. 1989. Rotifer as food in aquaculture. Hydrobiologia, 186(18): 399-400.

Lubzens, E. \& Zmora, O. 2003. Production and nutritional value of rotifers. In: Life feeds in marine aquaculture. (Eds.) J.G. StØttrup and L.A. McEvoy. Blackwell Science Ltd, p. 17-64.

Lunger, A.N., McLean, E., Gaylord, T.G., Khun, D., \& Craig, S.R. 2007. Taurine supplementation to alternative dietary proteins used in fish meal replacement enhances growth of juvenile cobia (Rachycentron canadum). Aquaculture, 271: 401-410.

Martinez, J.B., Chatzifotis, S., Divanachi, P., \& Takeuchi, T. 2004. Effect of dietary taurine supplementation on growth performance and feed selection of sea bass Dicentrarchus labrax fry fed with demandfeeders. Fisheries science, 70(1): 74-79.

Melianawati, R., Andamari, R., Astuti, N.W.W., \& Suwirya, K. 2010. Perbaikan teknik produksi massal benih kerapu bebek dan sunu bermutu baik dan kontinyu. Laporan Proyek Riset Perikanan Budidaya Laut Gondol-Bali, 15 pp. Tidak dipublikasi.

Park, G., Takeuchi, T., Seikai, T., \& Yokoyama, M. 2001. The Effects of dietary taurine on growth and taurine levels in whole body of juvenile Japanese Flounder Paralichthys olivaceus. Nippon Suisan Gakkaishi, 67(2): 238-243.

Putra, A.N. 2008. Aplikasi pemberian taurine pada larva ikan kerapu bebek Cromileptes altivelis. Fakultas Perikanan dan IImu Kelautan, Institut Pertanian Bogor, $66 \mathrm{hlm}$.

Rosner, B. 1995. Fundamentals of biostatistics $4^{\text {th }}$ eds. Duxbury Press.

Ruchyani, S. 2006. Pengaruh rotifer yang diperkaya dengan taurin pada kadar yang berbeda terhadap kelangsungan hidup dan perkembangan stadia larva udang vaname Litopenaeus vannamei. Fakultas Perikanan dan IImu Kelautan, Institut Pertanian Bogor, $36 \mathrm{hlm}$.

Sakaguchi, M., Murata, M., Daikoku, T., \& Arai, S. 1988. Effect of dietary taurine on whole body and tissue taurine levels of Guppy and Eel. Nippon Suisan Gakkaishi, 54(9): 1647-1652.

Sugama, K., Tridjoko, Slamet, B., Ismi, S., Setiadi, E., \& Kawahara, S. 2001. Petunjuk teknis produksi benih ikan kerapu bebek, Cromileptes altivelis. Balai Riset Budidaya Laut Gondol, Pusat Riset dan Pengembangan Eksploritasi Laut dan Perikanan, Departemen Kelautan dan Perikanan dan Japan International Cooperation Agency, $40 \mathrm{hlm}$.

Suwirya, K., Prijono, A., Hanafi, A., Andamari, R., Melianawati, R., Marzuqi, M., Sugama, K., \& Giri, N.A. 2006. Pedoman teknis pembenihan ikan kerapu sunu (Plectropomus leopardus). Pusat Riset Perikanan Budidaya, $18 \mathrm{hlm}$.

Takeuchi, T. 2001. A review of feed development for early life stages of marine finfish in Japan. Aquaculture, 200(1-2): 203-222. 